\title{
Vs30 Mapping and Soil Classification in The Southern Part of Kulon Progo Using Rayleigh Wave Ellipticity Inversion
}

\author{
Bambang Sunardi $^{1}$, Siti Naimah ${ }^{2}$, Urip Haryoko ${ }^{1}$, Supriyanto Rohadi ${ }^{1}$, Sulastri $^{1}$, Rasmid ${ }^{1}$ \\ ${ }_{1}^{1}$ Research and Development center, Meteorological, Climatological, and Geophysical Agency, Jl. Angkasa 1 No. 2, Kemayoran, Jakarta \\ 2 Geophysical Engineering, Faculty of Mining and Petroleum Engineering, Bandung Institute of Technology, Jl.Ganesha No. 10, Bandung
}

\section{Article History:}

Received 18 October 2018

Received in revised form 5 December 2018

Accepted 17 December 2018

Available online 31 January 2019

Keywords:

Vs30, soil classification, inversion, rayleigh wave ellipticity, Kulon Progo

\section{Corresponding Author:}

Bambang Sunardi

Email: b.sunardi@gmail.com

\begin{abstract}
Shear wave velocity from the ground surface to a depth of 30 meters (Vs30) is a parameter to determine dynamic characteristics of the soil, which can be used to assess the level of seismic hazard. Thus, Vs30 mapping has an important role in seismic hazard mitigation efforts. Vs30 can be determined by Multichannel Analysis of Surface Waves (MASW) and Spatial Autocorrelation (SPAC) methods. A simpler alternative can be done by using Rayleigh wave ellipticity. The main objective of this research is to map Vs30 in the southern part of Kulon Progo using Rayleigh wave ellipticity inversion. In this study, Rayleigh wave ellipticity inversion was performed on 42 microtremor single measurement data, scattered in the southern part of Kulon Progo. The inversion results are used to estimate the value of Vs30 and classify the soil type at the measurement points, referring to SNI 1726:2012. A Vs30 distribution map and soil type classification are obtained by applying the geostatistical interpolation method. The mapping result showed that most of the southern part of Kulon Progo has a relatively low Vs30 value. These values are in the range of $180-342 \mathrm{~m} / \mathrm{s}$, which categorized as stiff soil (SD). In this region, some parts located in the hilly and transition zones have relatively high shear wave velocities in the range of 357$578 \mathrm{~m} / \mathrm{s}$ and included in the category of very dense soil/soft rock (SC) types.
\end{abstract}

(C) Author(s) 2018. This is an open access article under the Creative Commons Attribution-ShareAlike 4.0 International License (CC BY-SA 4.0).

\section{Pendahuluan}

Kecamatan Temon, Wates, Panjatan, Galur, dan Lendah merupakan wilayah di Kulon Progo bagian selatan yang rawan terdampak gempabumi. Sebagai contoh, gempabumi yang berpusat di Bantul pada 26 Mei 2006 dengan magnitudo 5,9 SR mengakibatkan 22 korban jiwa dan 2.179 korban luka-luka di Kulon Progo (BMKG, 2015). Sejumlah infrastuktur di Kulon Progo juga mengalami kerusakan, 4.009 unit rumah rusak berat dan 5.134 unit rumah rusak ringan (Humas DIY, 2018; BNPB, 2018). Total kerugian untuk daerah Kulon Progo ditaksir mencapai 1,3 triliun rupiah (Bappenas, 2006).

Upaya yang dapat dilakukan untuk mitigasi gempabumi salah satunya melalui analisis bahaya gempabumi. Salah satu tahapan penting dalam analisis bahaya gempabumi adalah investigasi bawah permukaan untuk mengetahui karakteristik dinamis tanah. Karakteristik dinamis tanah salah satunya dapat dilakukan dengan memperkirakan nilai kecepatan gelombang geser (Sunardi, 2017). Untuk mengklasifikasi jenis tanah maupun keperluan geoteknik, umumnya menggunakan kecepatan gelombang geser dari permukaan tanah hingga kedalaman 30 meter atau dikenal dengan Vs30 sebagai acuan (Kanli, dkk., 2006; SNI 1726:2012).

Kecepatan gelombang geser dari permukaan tanah hingga kedalaman 30 meter (Vs30) merupakan parameter penting dalam prediksi gerakan tanah maupun studi efek tanah lokal terhadap goncangan gempabumi. Vs30 merupakan indikator kunci dari respons tanah yang umumnya mendominasi amplifikasi gerakan tanah akibat gempabumi (Lee and Tsai, 2008). Salah satu cara sederhana untuk menghitung bahaya gempabumi dalam kaitannya dengan mitigasi bencana tersebut adalah dengan menggunakan Vs30 untuk mengklasifikasikan jenis tanah (Wills, dkk., 2000).

Beberapa metode geofisika telah dikembangkan untuk mendapatkan profil kecepatan gelombang geser (Vs). Pengeboran akan memberikan gambaran struktur yang baik, namun memakan waktu dan biaya yang tidak murah. 
Seismik refleksi dan refraksi membutuhkan sumber aktif, namun umumnya menghasilkan gelombang frekuensi tinggi sehingga tidak dapat terpenetrasi ke lapisan yang sangat dalam. Cara lain yang dikembangkan adalah dengan menggunakan getaran seismik alamiah, atau sering disebut mikrotremor (Hobiger, dkk., 2013).

Mikrotremor merupakan getaran tanah yang dapat bersumber dari alam seperti gelombang laut, angin, atmosfer, dan juga aktivitas manusia seperti lalu lintas, industri, dan lain-lain (Konno dan Ohmachi, 1998). Mikrotremor di definisikan sebagai getaran tanah yang kecil dan terus-menerus yang bersumber dari berbagai macam getaran dan saling beresonansi (Kanai dan Tanaka, 1961). Array sensor seismik dapat digunakan untuk memperkirakan kurva dispersi gelombang permukaan yang selanjutnya dapat diinversi sehingga diperoleh struktur kecepatan gelombang geser hingga batuan dasar. Namun demikian, pengukuran semacam ini masih relatif membutuhkan waktu yang lebih lama, disamping kendala infrastruktur yang membatasi kemungkinan lokasi penempatan array sensor seismik itu sendiri (Hobiger, dkk., 2013).

Salah satu metode alternatif yang lebih sederhana dapat diterapkan dengan memanfaatkan eliptisitas gelombang Rayleigh yang dapat diukur dengan menggunakan sensor seismik tunggal (single mikrotremor). Metode tersebut mengasumsikan bahwa gelombang permukaan mendominasi data mikrotremor dan bentuk kurva $\mathrm{H} / \mathrm{V}$ sebagian besar didominasi oleh eliptisitas gelombang Rayleigh (Irfan, 2017). Gelombang Rayleigh merupakan jenis gelombang permukaan yang terbentuk akibat interferensi gelombang-gelombang pantul P dan SV yang sudut datangnya melebihi sudut kritis. Gerak partikel medium ketika dilewati oleh gelombang ini berbentuk elips dimana merupakan kombinasi dari gerak partikel gelombang P dan SV (Afnimar, 2009). Rasio gerakan partikel horizontal dan vertikal inilah yang disebut eliptisitas gelombang Rayleigh (Hobiger, 2013).

Eliptisitas gelombang Rayleigh telah digunakan pada tahun 1969 untuk menentukan struktur bawah permukaan (Boore dan Toksoz, 1969). Berdasarkan penelitian tersebut, secara umum eliptisitas dan kecepatan fase sama-sama sensitif terhadap gangguan struktural. Namun lapisan sedimen dekat permukaan yang memiliki kecepatan rendah, jauh lebih kuat dipengaruhi oleh eliptisitas daripada kecepatan fase (Boore dan Toksoz, 1969). Belakangan, penggunaan eliptisitas gelombang Rayleigh untuk menentukan struktur bawah permukaan semakin diminati. Poggi menerapkan penggunaan eliptisitas gelombang Rayleigh untuk kajian bahaya seismik dan mikrozonasi di Lucerne, Switzerland (Poggi, 2012). Sementara itu di Eropa, Hobiger menggunakan inversi eliptisitas gelombang Rayleigh untuk memetakan struktur tanah (Hobiger, 2013).

Penelitian ini bertujuan untuk memetakan nilai kecepatan gelombang geser rata-rata hingga kedalaman $30 \mathrm{~m}$ (Vs30) dan mengklasifikasikan jenis tanah di wilayah Kulon Progo bagian selatan dengan memanfaatkan inversi eliptisitas gelombang Rayleigh dari data single mikrotermor. Klasifikasi jenis tanah berdasarkan nilai Vs30 dapat dimanfaatkan untuk menilai tingkat kerawanan gempabumi di suatu tempat, sehingga potensi kerusakan dan kerugian akibat gempabumi dapat dikurangi.

\section{Data dan Metodologi}

Amplifikasi getaran tanah dipengaruhi salah satunya oleh nilai kecepatan gelombang geser (Vs) terhadap kedalaman. Amplifikasi gempabumi akan sebading dengan persamaan (1).

$$
\frac{1}{\sqrt{V_{s} \cdot \rho}}
$$

Dimana Vs merupakan kecapatan gelombang geser dan $\rho$ adalah densitas tanah setempat (Aki dan Richards, 1980). Saat densitas relatif konstan, profil Vs terhadap kedalaman dapat dipergunakan untuk mengkarakterisasi kondisi tanah setempat. Pada penelitian ini, kita memperkirakan Vs30 dan mengklasifikasi jenis tanah di wilayah Kulon Progo bagian selatan dengan memanfaatkan metode inversi eliptisitas gelombang Rayleigh yang diperoleh dari data pengukuran single mikrotremor di wilayah tersebut.

\subsection{Data dan Lokasi}

Sejumlah 42 data pengukuran single mikrotremor di wilayah Kulon Progo bagian selatan digunakan dalam penelitian ini. Sebaran titik pengukuran single mikrotremor ditunjukkan pada Gambar 2.1. Pengambilan data mikrotremor dilakukan menggunakan TDS (Taide Digital Seismograph) dengan digitizer tipe TDL-303 dan seismometer tipe DS-4A Short Period dengan frekuensi sampling $100 \mathrm{~Hz}$ dan durasi perekaman selama 30 menit. Data rekaman single mikrotremor terdiri dari tiga komponen yaitu komponen vertikal (Z), komponen horizontal timur-barat (E), dan komponen horizontal utara-selatan $(\mathrm{N})$ dalam format miniseed seperti terlihat pada Gambar 2.2.

\subsection{Metodologi}

Eliptisitas gelombang Rayleigh merupakan rasio antara gerakan partikel horizontal dan vertikal. Untuk mendapatkan kurva eliptisitas tersebut, data mikrotremor diekstrak menggunakan metode Horizontal to Vertical Time-Frequency Analysis (HVTFA). Representasi komponen horizontal dan vertikal dihitung dengan menggunakan Continous Wavelet Transform (CWT) seperti dirumuskan dalam persamaan (2).

$$
C W T_{\{x\}(a, b)}=\frac{1}{\sqrt{|a|}} \int_{-\infty}^{\infty} x(t) \psi^{*}\left(\frac{t-b}{a}\right) \cdot d t
$$

Dimana, $a$ adalah parameter dilatasi dan $b$ adalah parameter translasi. Jika $t$ adalah waktu, maka $a$ berbanding terbalik dengan frekuensi dan $b$ merupakan translasi dalam waktu. 


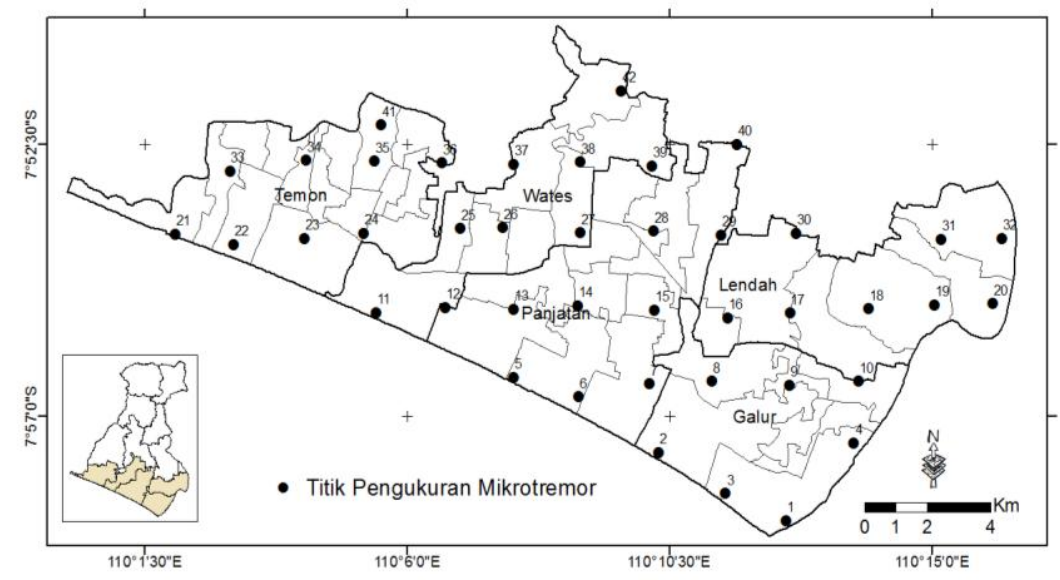

Gambar 2.1 Distribusi titik pengukuran single mikrotremor di wilayah Kulon Progo bagian selatan.

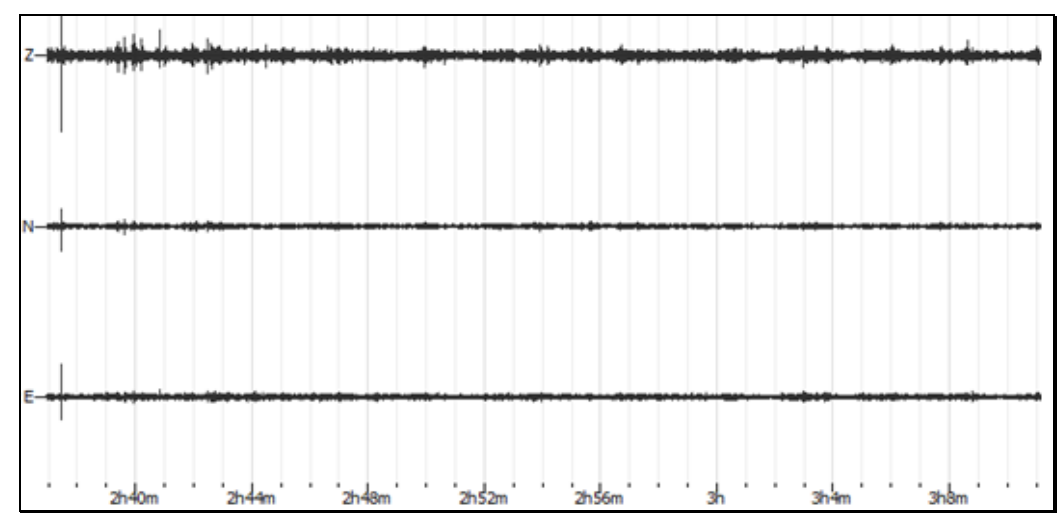

Gambar 2.2 Contoh data rekaman single mikrotremor terdiri dari tiga komponen Z, N dan E.

Algoritma yang digunakan pada analisis HVTFA meliputi DC removal pada ketiga komponen, spektrum fourier, serta modifikasi wavelet Morlet dalam domain frekuensi. Selanjutnya sinyal kompleks dari komponen horizontal digabungkan dengan kombinasi vektorial seperti dirumuskan dalam persamaan 3 (Atashband dan Esfahanizadeh, 2012).

$$
\sqrt{\text { North }^{2}+\text { East }^{2}}
$$

Proses selanjutnya menghitung nilai absolut dari kompleks vertikal dan kompleks horizontal gabungan. Untuk setiap maksimum (termasuk maksimum lokal) pada komponen vertikal, waktu dan amplitudo disimpan. Proses tersebut diulang untuk setiap frekuensi yang dipilih (Atashband dan Esfahanizadeh, 2012). Dalam penelitian ini, analisis data single mikrotremor menggunakan nilai parameter wavelet $(\mathrm{m}) 10$ dan jumlah puncak per menit 10 .

Setelah kurva eliptisitas diperoleh, tahap selanjutnya adalah inversi untuk mendapatkan profil kecepatan gelombang geser (Vs). Parameter-parameter model awal mencerminkan karakteristik dinamis suatu tempat seperti halnya Vp, Vs, rasio poisson, dan masa jenis batuan. Proses inversi didasarkan pada teknik Monte Carlo atau conditional neighbourhood algorithm (Sambridge, 1999).
Dari model awal ini, perhitungan misfit yang bersesuaian dilakukan menggunakan persamaan (4).

$$
\text { misfit }=\sqrt{\frac{1}{N} \cdot \sum_{i=1}^{N}\left(\frac{D_{i}-M_{i}}{\sigma_{i}}\right)^{2}}
$$

Dimana $N$ adalah jumlah titik data, $D_{i}$ adalah data hasil inversi, $M_{i}$ adalah model struktur tanah, dan $\sigma_{i}$ merupakan standar deviasi dari data hasil inversi dengan $1 \leq i \leq N$. Jika nilai misfit yang dihasilkan masih tinggi (>1) maka perlu dilakukan perubahan pada parameter model awal. Pada akhirnya, misfit dengan nilai terendah $(0 \leq$ misfit $<1)$ akan digunakan sebagai model terbaik.

Untuk menentukan nilai kecepatan gelombang geser hingga kedalaman $30 \mathrm{~m}$ (Vs30) dihitung menggunakan persamaan (5).

$$
V_{S 30}=\frac{30}{\sum_{i=1}^{N}\left(\frac{h_{i}}{v_{i}}\right)}
$$

Dimana $h_{i}$ dan $V_{i}$ masing-masing menyatakan ketebalan (dalam meter) dan kecepatan gelombang geser (dalam $\mathrm{m} / \mathrm{s}$ ) pada lapisan ke- $i$ dari total $N$ lapisan di atas $30 \mathrm{~m}$. Hasil Vs30 yang didapatkan kemudian dipetakan dan dianalisis.

Klasifikasi jenis tanah dapat dilakukan berdasarkan data Vs30 dengan mengacu pada ketentuan yang 
tercantum dalam SNI 1726:2012 sebagaimana ditunjukkan pada Tabel 3.1. Nilai Vs dalam tabel merupakan nilai rata-rata dari kecepatan gelombang geser sampai kedalaman $30 \mathrm{~m}$ di bawah permukaan tanah (Vs30). Secara umum, metodologi penelitian dapat ditunjukkan dalam diagram alir Pada Gambar 3.1.

\section{Hasil dan Pembahasan}

Output dari inversi eliptisitas gelombang Rayleigh salah satunya adalah profil kecepatan gelombang geser (Vs) di titik-titik pengukuran single mikrotremor di wilayah Kulon Progo bagian selatan. Selanjutnya distribusi kecepatan gelombang geser diperhitungkan hingga kedalaman $30 \mathrm{~m}$ berdasarkan profil-profil Vs yang diperoleh.

\subsection{Profil Kecepatan Gelombang Geser (Vs)}

Sifat material tanah umumnya disajikan dalam bentuk model lapisan bumi di mana sifat-sifatnya hanya berubah secara vertikal dan diwakili oleh kumpulan lapisan-lapisan yang khas. Setiap lapisan kemudian dianggap sebagai medium yang homogen dengan sifat seismik yang sama seperti halnya kecepatan gelombang P dan S (Vp dan Vs), serta densitas. Perubahan properti yang lebih cepat pada kedalaman dangkal, menyebabkan ketebalan setiap lapisan dalam model bumi berlapis cenderung lebih kecil di bagian atas, dan akan meningkat seiring dengan kedalaman (Park Seismic LLC, 2018).

Dalam penelitian ini diperoleh 42 profil kecepatan gelombang geser (Vs) di titik-titik pengukuran single mikrotremor yang dianggap mewakili wilayah Kulon Progo bagian selatan. Gambar 3.2 dan 3.3 merupakan contoh hasil inversi eliptisitas gelombang Rayleigh di titik pengukuran 1, 5, 25 dan 42. Profil kecepatan gelombang geser (Vs) yang dihasilkan pada setiap titik pengukuran menunjukkan perbedaan jenis batuan di bawah permukaan. Semakin lunak batuan, nilai kecepatan gelombang geser (Vs) akan semakin kecil dikarenakan nilai Vs berbanding lurus dengan densitas (kerapatan) batuan. Semakin kecil densitas batuan maka kecepatan gelombang geser juga akan semakin kecil dan berlaku sebaliknya. Estimasi nilai Vs akan bermanfaat dalam memperkirakan litologi bawah permukaan dan mengklasifikasikan jenis tanah di lokasi tersebut.

\subsection{Distribusi Vs30}

Vs30 ditentukan berdasarkan profil Vs yang telah diperoleh sebelumnya. Estimasi nilai Vs30 di masingmasing titik pengukuran single mikrotremor dilakukan menggunakan perhitungan pada persamaan (5). Distribusi Vs30 di Kulon Progo bagian selatan diperlihatkan pada Gambar 3.4.

Secara umum nilai Vs30 di wilayah Kulon Progo bagian selatan bervariasi dari 180 hingga 578 m/s. Sebaran nilai Vs30 dalam kisaran 180-342 m/s dijumpai di Temon bagian selatan, Wates bagian selatan, Panjatan bagian selatan, dan Galur serta sebagian Lendah. Di wilayah penelitian, beberapa bagian yang terletak di zona perbukitan dan zona transisi memiliki kecepatan gelombang geser yang relatif lebih tinggi pada kisaran
357-578 m/s diantaranya Temon bagian utara, Panjatan bagian utara, Wates bagian utara serta Lendah bagian utara.

\subsection{Klasifikasi Jenis Tanah}

SNI 1726:2012 mengklasifikasikan tanah berdasarkan nilai Vs30. Jenis tanah diklasifikasikan menjadi tanah lunak (SE) dengan nilai Vs kurang dari $175 \mathrm{~m} / \mathrm{s}$, tanah sedang (SD) dengan nilai Vs 175 hingga kurang dari 350 $\mathrm{m} / \mathrm{s}$, tanah keras / batuan lunak (SC) dengan nilai Vs lebih dari 350 hingga kurang dari $750 \mathrm{~m} / \mathrm{s}$, batuan (SB) dengan nilai Vs lebih dari 750 hingga kurang dari $1500 \mathrm{~m} / \mathrm{s}$ serta batuan keras (SA) dengan nilai Vs lebih dari 1500 m/s.

Secara umum, klasifikasi tanah di wilayah Kulon Progo bagian selatan berdasarkan nilai Vs30 terbagi menjadi tanah sedang (SD) dan tanah keras / batuan lunak (SC). Gambar 3.5 menunjukan distribusi jenis tanah di Kulon Progo bagian Selatan mengacu pada standar SNI 1726:2012. Sebagian besar daerah di Kulon Progo bagian selatan memiliki jenis tanah sedang (SD). Beberapa bagian yang terletak di zona perbukitan dan zona transisi dengan Vs30 yang relatif lebih tinggi masuk dalam kategori jenis tanah keras (SC).

Tabel 3.1 Klasifikasi jenis tanah (SNI 1726:2012)

\begin{tabular}{lc}
\hline \multicolumn{1}{c}{ Klasifikasi Tanah } & Vs $(\mathbf{m} / \mathbf{s})$ \\
\hline SE (Tanah Lunak) & $<175$ \\
SD (Tanah Sedang) & $175<$ Vs $\leq 350$ \\
SC (Tanah Keras, Batuan Lunak) & $350<$ Vs $\leq 750$ \\
SB (Batuan) & $750<$ Vs $\leq 1500$ \\
SA (Batuan Keras) & $>1500$ \\
\hline
\end{tabular}

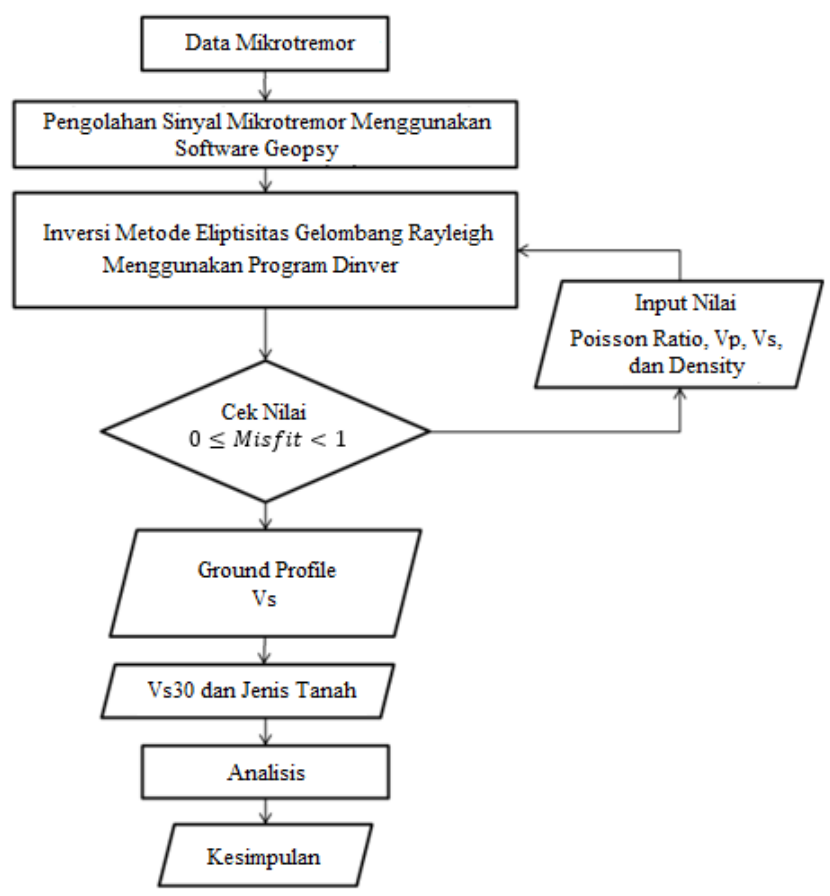

Gambar 3.1 Diagram alir penelitian. 

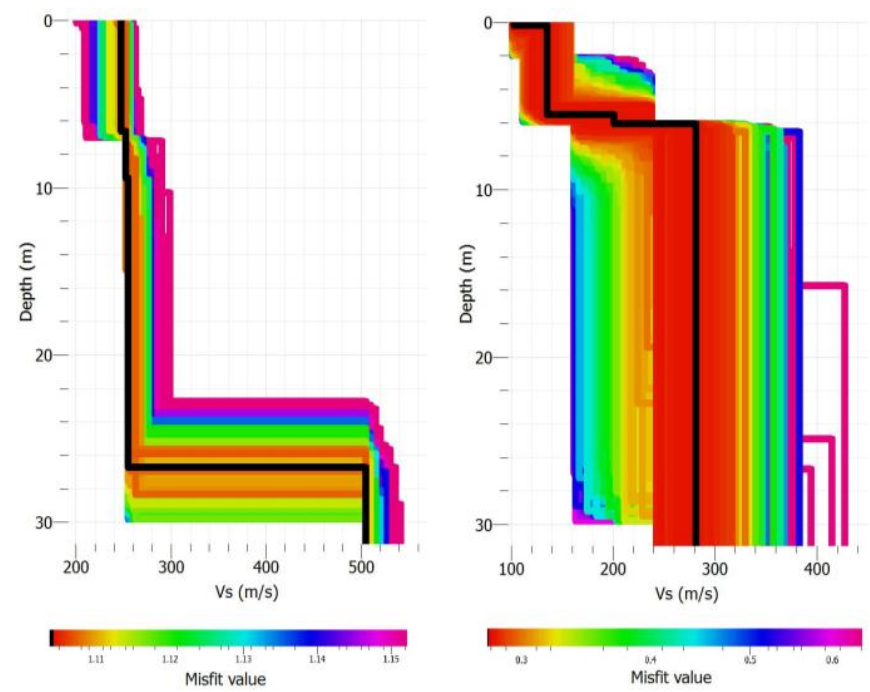

Gambar 3.2 Profil Kecepatan Gelombang Geser (Vs) di titik pengukuran 1 (kiri) dan 5 (kanan).
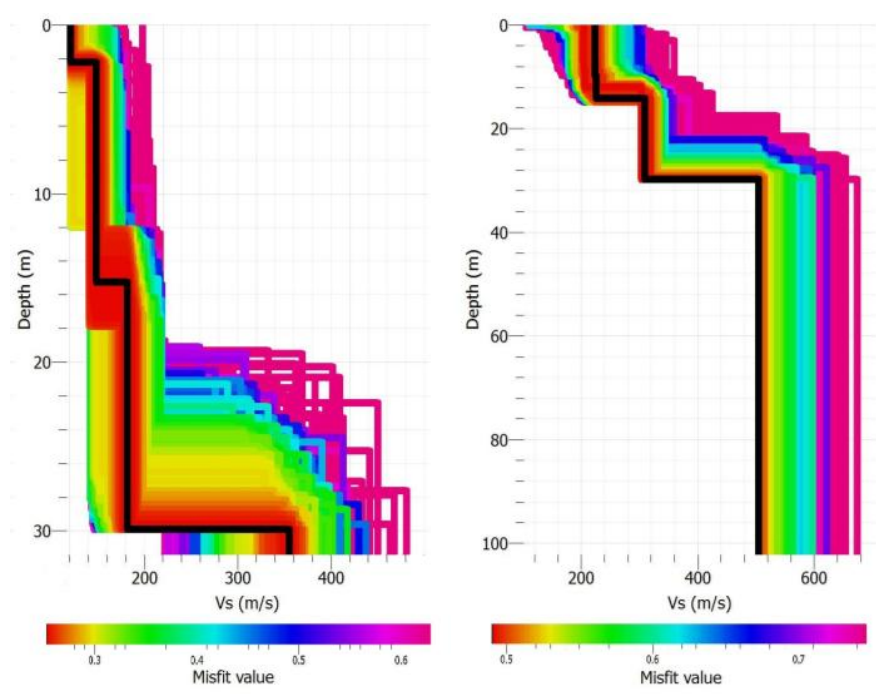

Gambar 3.3 Profil Kecepatan Gelombang Geser (Vs) di titik pengukuran 25 (kiri) dan 42 (kanan).

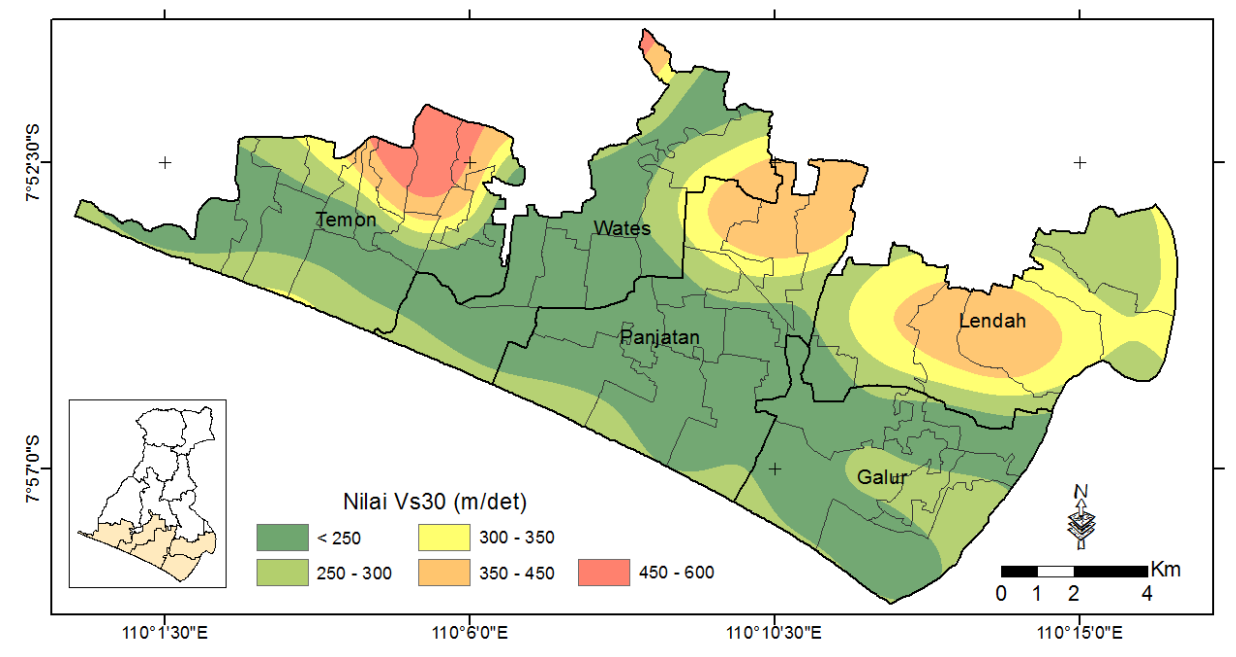

Gambar 3.4 Distribusi Vs30 wilayah Kulon Progo bagian selatan.

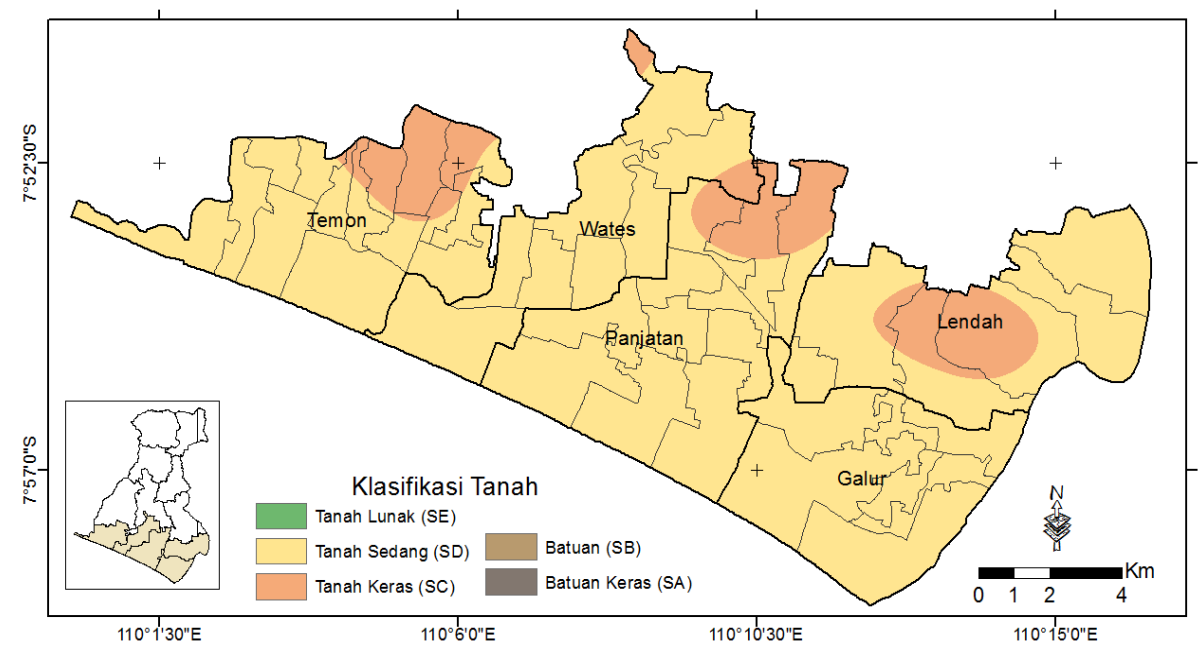

Gambar 3.5 Klasifikasi tanah di wilayah Kulon Progo bagian selatan. 


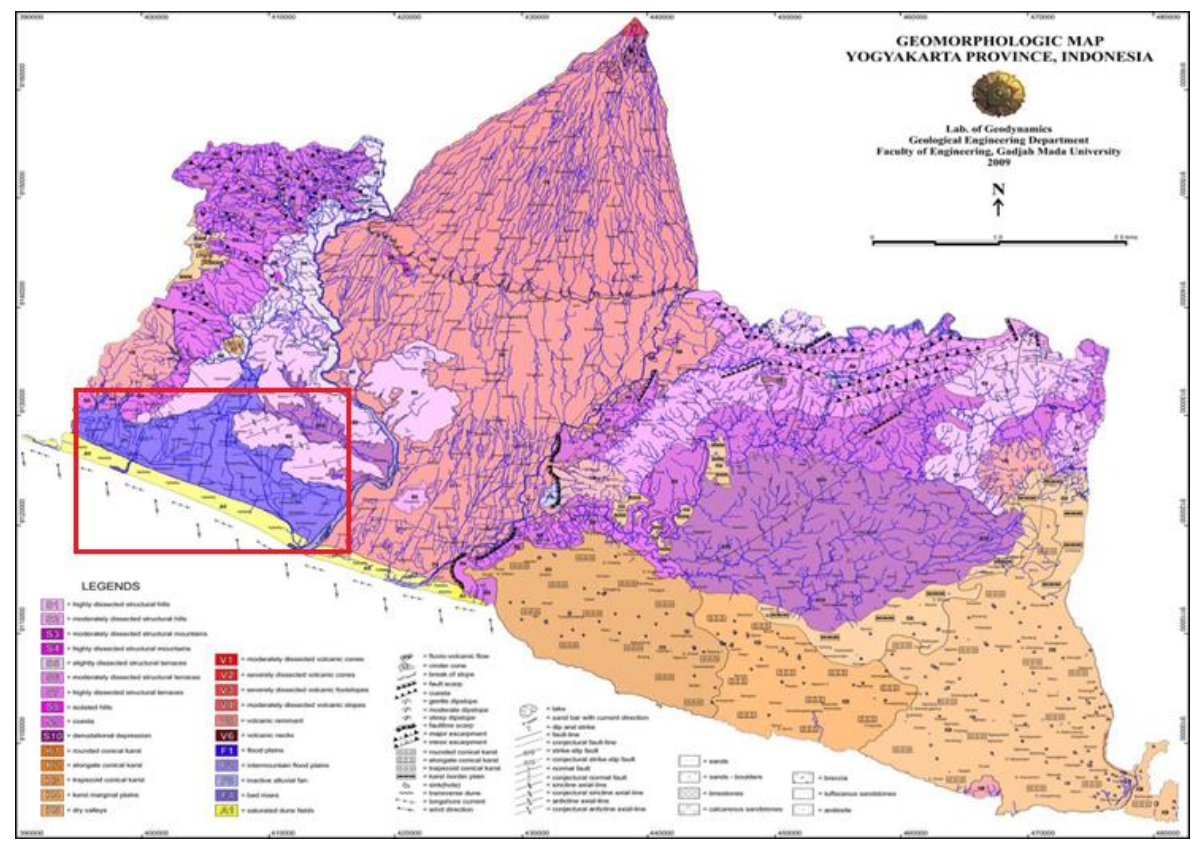

Gambar 3.6 Peta Geomorfologi Daerah Istimewa Yogyakarta. Daerah yang dibatasi oleh garis merah menunjukkan letak wilayah Kulon Progo bagian selatan (Modifikasi Husein dan Srijono, 2010).

Jika dilihat dari kondisi geomorfologi (Gambar 3.6), wilayah Temon bagian utara terletak di daerah perbukitan dan pegunungan stuktural terbiku kuat. Salah satu jenis batuan utama yang membentuk struktur ini adalah breksi andesit (Husein dan Srijono, 2010). Hasil pemetaan Vs30 dan jenis tanah apabila dibandingkan dengan geomorfologi setempat menunjukkan adanya kesesuaian. Semakin keras material tanah, maka kecepatan gelombang geser (Vs) yang melaluinya akan semakin tinggi dan sebaliknya.

Penelitian lanjutan menggunakan metode geofisika lainnya seperti halnya Multi Chanel Surface Wave (MASW) maupun array mikrotremor dapat dipergunakan untuk memperkuat hasil analisis. Validasi hasil juga dapat dilakukan dengan menggunakan data bor yang berada di wilayah penelitian.

\section{Kesimpulan}

Hasil pemetaan kecepatan gelombang geser hingga kedalaman $30 \mathrm{~m}$ (Vs30) dengan memanfaatkan inversi eliptisitas gelombang Rayleigh menunjukkan sebagian besar wilayah Kulon Progo bagian selatan memiliki nilai Vs30 yang relatif rendah dalam kisaran $180-342 \mathrm{~m} / \mathrm{s}$, dengan demikian masuk dalam kategori jenis tanah sedang (SD). Beberapa bagian yang terletak di zona perbukitan dan zona transisi memiliki kecepatan gelombang geser yang relatif lebih tinggi di kisaran 357 $578 \mathrm{~m} / \mathrm{s}$ sehingga masuk dalam kategori jenis tanah keras (SC).

\section{Pernyataan Konflik Kepentingan}

Penulis menyatakan tidak ada konflik kepentingan dalam artikel ini (The authors declare no competing interest).

\section{Referensi}

Afnimar (2009). Seismologi. ITB Bandung.

Aki, K., dan Richards, P.G. (1980). Quantitative Seismology. W. H. Freeman \& Co., San Francisco.

Atashband, S., dan Esfahanizadeh, M. (2012). Effects Evaluation of Ambient Vibration Recodring Conditions on HVTFA Results. Proceedings of the 15th World Conference on Earthquake Engineering, Lisbon, Portugal.

Bappenas. (2006). Penilaian Awal Kerusakan dan Kerugian Bencana Alam di Yogyakarta dan Jawa Tengah. Bappenas.

BMKG, Pusat Gempabumi dan Tsunami. (2015). Katalog Gempabumi Merusak 1821-2014. BMKG Jakarta.

BNPB. (2018). Data Informasi Bencana Indonesia. http://bnpb.cloud/dibi/laporan4 (diakses 17 Juli 2018).

Boore, D.M., dan Toksoz, M.N. (1969). Rayleigh wave particle motion and crustal structure. Bull. seism. Soc. Am. 59, 331-346.

Hobiger, M., Cornou, C., Wathelet, M., Giulio, G.D., Endrun, B.K., dkk. (2013). Ground structure imaging by inversions of Rayleigh wave ellipticity: sensitivity analysis and application to European strongmotion sites. Geophys. J. Int. 192, 207-229.

Humas DIY. (2018). Data dan Informasi Bencana oleh Humas DIY tanggal 28 November 2013. Humas DIY. https https://jogjaprov.go.id/berita/detail/datadan-informasi-bencana (diakses 17 Juli 2018).

Husein, S., dan Srijono (2010). Peta Geomorfologi Daerah Istimewa Yogyakarta. Prosiding Simposium Geologi Yogyakarta, Yogyakarta, Indonesia, pp941-944. 
Irfan, U. (2017). Near-surface characterization from the $\mathrm{H} / \mathrm{V}$ spectral curves along with the joint inversion of the ellipticity and dispersion curves. Tesis, University of Sao Paulo.

Kanai, K., dan Tanaka, T. (1961). On Microtremors VIII. Bulletin of the Earthquake Research Institute 39, 97-114.

Kanli, A.I., Tildy, P., Pronay, Z., Pinar, A., Hermann, L. (2006). Vs30 mapping and soil classification for seismic site effect evaluation in Dinar region, SW Turkey. Geophysical Journal International 165, 223-235.

Konno, K., dan Ohmachi, T. (1998). Ground Motion Characteristics Estimated from Spectral Ratio beetwen Horizontal and Vertical Components of Microtremor. Bull. Seism. Soc. Am. 88, 228-241.

Lee, C. T., and Tsai, B. R. (2008). Mapping Vs30 in Taiwan. Terr. Atmos. Ocean. Sci. 19 (6), 671-682.

Park Seismic LLC. (2018). How to Calculate Average Vs and Vs30m. http://www.parkseismic.com/SSCHowToCalculateVs30m.html (diakses 1 Oktober 2018).

Poggi, V., Fah, D., Burjanek, J., Giardini, D. (2012). The use of Rayleigh - wave ellipticity for site - specific hazard assessment and microzonation: application to the city of Lucerne, Switzerland. Geophysical Journal International 188 (3), 11541172.

Sambridge, M. (1999). Geophysical inversion with a neighbourhood algorithm-II. Appraising the ensemble. Geophys. J Int. 138, 727-746.

SNI 1726:2012. (2012). Tata cara perencanaan ketahanan gempa untuk struktur bangunan gedung dan non gedung.

http://sisni.bsn.go.id/index.php?/sni_main/sni/d etail_sni/14568 (diakses 17 Juli 2018).

Sunardi, B., Putri, E.N., Susilanto, P. dan Ngadmanto, D. (2017). Penerapan metode inversi HVSR untuk pencitraan 3-D kecepatan gelombang geser (Vs) di Kulon Progo bagian selatan. Jurnal Riset Geofisika Indonesia. 1, 47-53.

Wills, C. J., Petersen, M. D., Bryant, W. A., Reichle, M., Saucedo, G. J., Tan, S., Taylor, G., and Treiman, J. (2000). A Site Conditions Map for California Based on Geology and Shear Wave Velocity. Bull. Seism. Soc. Am. 90 (6), S187-S208. 